\begin{tabular}{lr} 
DE & $\begin{array}{l}\text { DE GRUYTER } \\
\text { OPEN }\end{array}$ \\
\hline & STUDIA UNIVERSITATIS BABESS-BOLYAI OECONOMICA \\
VOLUME 62, ISSUE 2, 2017, pp. 55-76 \\
DOI: $10.1515 /$ subboec-2017-0009
\end{tabular}

\title{
COMPETITIVE CONDITION OF SUB-SAHARAN AFRICA COMMERCIAL BANKS
}

Joseph Olorunfemi AKANDE*

University of KwaZulu-Natal, South Africa

\section{Farai KWENDA}

University of KwaZulu-Natal, South Africa

\begin{abstract}
This study assesses the competitive environment and the determinants of the Sub-Saharan Africa commercial banking sectors. We used the Lerner index that is generally acknowledged as the best at estimating the bank level competition and the Generalised Method of Moments (GMM) to study 440 commercial banks for the period 2006 to 2015 . We found a monopolistic competitive banking market. We also observed that competition is driven by the level of bank capital including some bank specific variables. Hence, we concluded that the banking market of the SSA region is contestable and competitive. As such, we recommend, among other things, that policy makers should device measures to ensure an ongoing competitive banking environment while stimulating other economic variables to complement this feat.
\end{abstract}

JEL classification: G21, L10

Keywords: competitive condition, Sub-Saharan Africa, commercial banks, Lerner index, Generalised Method of Moments.

\section{Introduction}

Competition has attracted attention in banking and finance literature for decades. An extensive body of theoretical and empirical studies has reported the significant role of bank competition in ensuring access to finance (Clarke et al., 2006; Lin et al., 2010; Love and Per'ia, 2014; Mudd, 2013; Rice and Strahan, 2010; Tan, 2013), efficiency (Mlambo and Ncube, 2011; Ningaye et al., 2014; Pasiouras et al., 2009; PruteanuPodpiera et al., 2008) and stability (Beck et al., 2013; Fu et al., 2014; Schaeck and

\footnotetext{
* Corresponding author. Address: School of Accounting, Economics and Finance, University of KwaZulu-Natal, Durban, South Africa, Email - akandeo.joseph@gmail.com
} 
Cin'ak, 2014; Ariss, 2010) in any economy. According to Casu et al. (2015), competition is good for many reasons; it is an essential force in any economy, it encourages firms to be more efficient and provide better allocation of resources. In banking, efficiency should entail lower costs, which should be passed to bank customers in the form of lower charges, higher deposit rates and reduced lending costs (Casu et al., 2015). Essentially, competition in banking improves access to finance, increases overall competitiveness in other sectors of an economy, fosters innovation and increases quality, widens consumer choice and promotes economic growth (Leon, 2015b). As it is the trend across the globe, Sub-Saharan Africa countries have witnessed quite a number of reforms of their financial sector that is predominantly banking in nature in the last two and a half decades. The thrust of these reforms has been the opening up of the financial system for competition to engender a robust banking system that is capable of harnessing the potentials of the region for economic growth. The main reforms which are homogeneous across the region include recapitalisation, liberalisation, privatisation, deregulation, removal of credit controls, establishment of new refinancing policies and relaxing of indigenisation policies. The region has made some good progress from these reforms, but whether they have translated to the much-anticipated competitive banking environment still leaves much to be desired. According to Mlachila et al. (2013) the banking system is highly concentrated and generally inefficient at financial intermediation. Basic indices of a competitive banking system like cost of banking, service charge, interest rate spread, interest costs are very high in this region compared with other regions of the world. The African Progress Panel (Panel, 2014b) in 2014 rose from its meeting to assert that stimulation of competition in the banking sectors will help to bridge interest rate spread that stifles savings and investments and consequently drive the needed economic growth in the region. How informed is this assertion? Is the SSA banking sector truly uncompetitive?

The essence of this study is then to investigate the competitiveness of the Sub-Saharan Africa commercial banks ${ }^{1}$. This becomes imperative because, the starting point of devising a good policy is for policy makers and regulators alike to know how the banking environment have reacted to existing regulations and policies that have been put in place in order to forge the possible way forward. This study contributes to extant literature in developmental finance. To the best of our knowledge, it is the first to comprehensively investigate the competitive condition of the banking sector of the region and using the Lerner index that is capable of analysing bank level competition. Available literature has only focused on a few individual countries in the region and in doing so focused on just the market and without analysing bank level competition. This is particularly necessary in the face of the increased tendencies towards regional integration. Our study revealed that, while considerable market power resides in the individual banks in the region, the market as a whole is highly contestable.

The other parts of this article are structured as follows. Section 2 reviews previous empirical literature and theories in light of how they affect the banking system. The study's methodology is considered in Section 3, then the results and analysis of results in Section 4 and finally Section 5 contains the summary and conclusion of the paper.

\footnotetext{
${ }^{1}$ Commercial banks account for more than $70 \%$ of the region's banking sector (Allen et al., 2011). According to Allen, Otchere, and Senbet (2011), SSA is underdeveloped and faces critical infrastructural challenges. Moreover, countries in this region share similar features in terms of the nature of their economies.
} 


\section{Literature review}

The efficiency, stability of a banking system and access to finance relate to the level of competitiveness of that banking sector (Love and Per'ia, 2014; Mudd, 2013; Ningaye et al., 2014; Fu et al., 2014; Schaeck and Cin'ak, 2014). Hence the need for a competitive banking system. But quite a number of reasons account for the imperfection in the banking sector and the fact that the conventional application of competition may not be admissible. These reasons range from regulatory requirements, charter value and capital requirements, existence of double market where a bank may want to create monopoly, for instance, in loan market and compete in the asset market, among others. The imperfections however do not suggest that the productive efficiency benefits of competition do not apply in the banking sectors. In this section, we review a range of relevant underpinning theories and empirical literature on competition in the banking system.

The concept of competition has a long history in economics and finance in which it is considered as a process of rivalry that in the long run forces price to equal the cost of production. It evolved into two major reviews, namely; competition as a static state and as a process of rivalry. The Cournot oligopoly theory formed the basis of the static state view. The static state view of competition defines the ideal of competition as an equilibrium condition because the price of costs approaches zero as the number of producers increases. According to this standard theory, competition is a static state in which firms cannot charge overprice and then earn abnormal profit. Competition as a process of rivalry was a product of the Austrian school under Schumpeter, Hayek and Von Mises who criticised the static state theory with the argument that the traditional neoclassical economists misused the term competition by applying it to a state instead of a process. They view competition as a complex process of rivalry between firms and related the core of competition to the behaviour of the firms in the market. This school's perspective maintained that a market is competitive when rivals are sufficiently aggressive to give an incumbent incentive to improve (lower price, better quality, etc.), in order to maintain its advantage. Competition thus acts as a selection mechanism through the destructive creative principle in which less efficient incumbents are removed and replaced by more efficient entrants.

The Chicago School Industrial Organisation approach on market structure theory extended these theories and argued that many if not most markets tend to approximate perfect competition in the long run. According to Posner (1979), positive profits in competitive markets are considered transitory since their presence stimulate entry yet result in their demise. Baumol et al. (1982) formalised this idea with the theory of contestability which states that markets behave competitively in the absence of entry and exit barriers. They argued that in a contestable market regulation is unnecessary as the threat of entry will both restrain incumbent market power and satisfy the requirement for static welfare maximisation. Market forces ensure that monopoly power will usually be short-lived such that the intensity of competition is unrelated to market structure but linked to market contestability. By contrast, the Austrian school argues that disequilibrium and monopoly power are the normal functioning of competitive markets. The contestability theory has a major impact on the conduct of competition policies and provides a framework to unify industrial organisation that is applicable in a wide range of industrial markets. Abdelkader and Mansouri (2013) argued an efficient industrial 
market pricing environment resulting from the threat of potential competition due to free entry and costless exits. The threat of potential competition guarantees an efficient banking system regardless of the existing players in the market (Dietsch, 1993). The empirical works of Claessens and Laeven (2004) found relevance of contestable market theory with number of banks and the level of market structure in their study of 50 countries market structure. Northcott et al. (2004) however found that the existence of regulation that promotes competition determines the workings of the theory.

Overall, most of these theories assumed a perfect competitive market with free entry and exit. However, the existence of friction in banking markets (for instance, barriers to entry, asymmetry information among others), is mitigating the direct application of the welfare theorem that is associated with perfect market, thus allowing room for the exercise of market power. Meanwhile, a healthy degree of rivalry is considered necessary for the dynamic efficiency of the sector, the principle that is at the basis of the trend towards fostering greater competition in banking markets across the globe.

Various attempts to test the foregoing theories have brought about a number of empirical models. The fact that the neoclassical conception poses some clear testable hypotheses explains the two strands of literature dominating the empirical measurement models in banking competition study, the structural and the nonstructural models which are based on the traditional and the new industrial organisation theory that are rooted in the competition as a static state. The structural model includes the structure conduct hypothesis (SHC), relative market power (RMP) and efficiency structure hypothesis (ESH). Structural models, (Shepherd, 1983; Smirlock et al., 1986; Chirwa, 2003), except ESH that found a reverse causality between structure and performance (Demsetz, 1973; Amidu, 2013), argued that structure causes performance. Non-structural models such as Lerner index (Lerner, 1934), PanzarRosse H-statistics (Panzar and Rosse, 1987, 1977), conjectural variation (Bresnahan, 1982; Lau, 1982; Iwata, 1974), Boone indicator (Boone, 2008a, b) and persistence of profits (Mueller, 1977, 1986) constitute the new empirical industrial organisation (NEIO), introduced in a number of attempts to collect empirical evidence on the nature of competition by observing conduct directly (a shortcoming of the structural models). Lerner index (Lerner, 1934), which is found to be consistent with the industrial organisation theory is employed in this study. The Lerner index measures market power as the difference between price and marginal cost expressed as a percentage of price. The market power of a bank is identified by the disparity between the bank's price and its marginal cost. The price and marginal cost should be equal in perfect competition, but will be at disequilibrium in an imperfect competitive market environment. A wide disparity between price and marginal cost is an indication of high market power. The Lerner index is hence a measure of the extent to which a bank is able to charge price above its marginal cost.

The theoretical foundation of the Lerner index is rooted in static oligopoly theory (Cournot model). Although the index has been around since in the mid-30s, its application in banking is relatively recent due to the inability to econometrically estimate price and marginal cost. Two approaches have been developed to surmount this, the production and intermediation approaches. The production approach considers banks' sole activities as servicing its account holders. Banks in this case offer a 
number of financial services such as savings and credit by mobilising labour and physical capital (Heffernan, 2005). Klein (1971); Monti (1972) and Sealey and Lindley (1977) used the intermediation approach as an alternative with the argument that banks intermediate between depositors and borrowers. Under this approach, it is believed that a bank employs labour and physical capital to attract deposits which are used to fund loans. In this approach, labour, physical capital and deposits are considered as inputs and proxy as costs while bank output is defined as total assets or total loan proxing as the price respectively. Furthermore, prices are not directly observable, researchers use balance sheets and income statements to infer prices. The marginal cost is estimated in two ways. The first is by estimating the average variable costs, defined as the total variable costs divided by the total assets or total income. This method, according to Casu et al. (2015), has the advantage of being straightforward but lacks in accuracy. The second approach requires the estimation of a cost function which is usually a translog cost function with a single output (total assets) and three input prices (deposits, labour and physical capital) based on the intermediation approach, see (Beck et al., 2013; Berger et al., 2009).

Many studies have empirically attempted to measure banking competition by averaging the individual Lerner indices. Weill (2013) analysed the evolution of bank competition measured with the Lerner index for the EU banks between 2002 and 2010 and obtained an index for all $27 \mathrm{EU}$ countries ranging from $12.20 \%$ to $20.34 \%$. This represented a highly competitive banking environment, but revealed a less improved competitive EU banking system compared to an earlier period of 1994 to 2004 conducted by Carb'o et al. (2009) with an index ranging from $11 \%$ to $22 \%$. De Guevara et al. (2007) observed an average of $20.45 \%$ for Spanish banking system between 1986 to 2002, likewise Maudos and Sol'ıs (2011) found that the Mexican banking system within 1993 and 2005 was monopolistically competitive. Agoraki et al. (2011), in a study of 13 CEE countries between 1998-2005; Ariss (2010), 60 developing countries including 14 African countries, 1999-2005; Amidu (2013), 55 developing countries inclusive of 22 African countries, 2000-2007; Beck et al. (2013) did a study of 79 countries between 1994-2009; Fu et al. (2014), 14 Asian countries between 2003 and 2010; Berger et al. (2009), 23 industrialised countries, 1999-2005; while employing competition as a variable in their various studies proxies Lerner index and found varied degree of market imperfection in the banking markets considered. We found just (Hussain and Mustapha, 2010) in literature that have considered the determinants of banking competition using banks specific variables in European Union banking sector including some Latin American countries. Their study covered the period 2000 to 2008 and with a panel OLS regression they found that banking market structure is dependent on the characteristics of the industry. They showed that NIM and ROA are negatively related to competition while ECR shows a positive relationship.

Only few empirical studies have measured competition of the banking sectors in the SSA region following the sweeping era of reforms. Without loss of generality, Kouki and Al-Nasser (2014) conducted a study on the implication of competition in 31 African countries, used Lerner index to compute their competition variable and found index waving between $58 \%$ in Sudan and $74 \%$ in Mauritania with an overall average of $62.21 \%$ between 2005 and 2010 . Given that his study capturing Africa as a continent did not take cognisance of the peculiarity of the SSA region, this constitutes the gap that this study proposes to fill by measuring the competitive condition 
of 37 SSA countries' commercial banking sectors for the period 2006 to 2015 using the Lerner index that is capable of measuring individual bank level competition in the short run and on year-on-year basis.

\section{Methodology}

A competitive banking environment drives efficiency, access to finance and stability (Casu et al., 2015). The goal of bank under competition according to the industrial organization theory is to manage its volume of loans and deposits such that its corresponding intermediation margin equals its technology Freixas et al. (2008). In other words, competitive banks induce savings by offering high deposit rate, as well as lower its real interest rate for loan to sell more; moreover, the contestable market theory argues that potential competition is enough to drive an efficient pricing banking system. The case is however different for a monopoly bank that is facing a downward sloping demand for deposits and an upward sloping supply for loan, giving it the power to charge very high price for loans and at same time low price for deposits. These suggest that for SSA to harness its potential for growth, its banks must be competitive to mobilize its savings and investment capabilities. It has been argued that SSA developmental aspiration will be unlocked once issues of competition in SSA banks are addressed (Panel, 2014a). Then the question is, how competitive is SSA commercial banks?

\subsection{Model Specification}

To answer this question, this study will compute the bank level competition index of the SSA commercial banks using Lerner index ${ }^{2}$ This method has been widely used in literature and in some studies of the degree of competitiveness of African banks, (see Aboagye et al. (2008) in Ghana, for one country study of SSA and Kouki and Al-Nasser (2014) for a panel of 31 countries in Africa). This study adopts the Lerner index because among its contemporaries, it is one of the most efficient competition measures following the outcome of the correlation of all indicators by Liu et al. (2013). In addition, the index allows for short term estimation and so can be used to compute competition of the banking market at any point in time, (Agoraki et al., 2011; Amidu, 2013; Ariss, 2010; Berger et al., 2009; Fu et al., 2014; Kouki and Al-Nasser, 2014). Finally, it is theoretically sound because it helps to locate the degree of competition between perfect competition and monopoly (Berger et al., 2009; Rojas, 2011). The Lerner index has been criticised by some scholars. There are divergent views on the estimation of price, for instance, while Casu and Girardone (2006) favoured both the traditional and non-traditional activities for price measurement, Molyneux et al. (1994) and Bikker and Haaf (2002), among others, considered just the traditional loan deposits services, this could result in the variation of Lerner index. In addition, it has been argued that the index ignores risk that formed a major part of the costs of banks and the attendant effect would mean inflated index (Tan, 2013). However, research has supported the use of both the traditional and

\footnotetext{
${ }^{2}$ For the purpose of hindsight, H statistics (Panzar and Rosse, 1987), Boone indicator (Boone, 2008a) conjectural variation approach (Iwata, 1974), persistence of profit (Mueller, 1977) are other alternative methods that could be used.
} 
non-traditional bank activities in price determination because of the increase in noninterest income overtime in banking (Ajisafe and Akinlo, 2013). Moreover, studies that have adjusted the Lerner index to risk found results that are not fundamentally different from the conventional Lerner index. Liu et al. (2013) conducted a correlation analysis of results of competition models and found that Lerner index is one of the two most valid measure of bank competition. To this extent, Lerner index approach which is modelled going forward is considered plausible for this study.

Given that the optimal output, $Q T Y_{i}$, of bank $i, i=1, \cdots, N$ at time $t$, is at the point where marginal cost, $M C_{i}$, equals its marginal revenue, $M R_{i}$, the ratio of the difference between the price, $P_{i}$, and the marginal cost, $M C_{i}$, on price is the Lerner index denoted as $L I_{i}$ and expressed algebraically as shown in equation (1.1), (see Flamini et al., 2009).

$$
L I_{i}=\frac{P_{i}-M C_{i}}{P_{i}}
$$

Where $P_{i}$ is the estimate of average price of bank production in country $i$ which is proxy by the ratio of bank total revenue to total assets (Berg and Kim, 1994; Berger et al., 2009; Carb'o et al., 2009; Fern'andez and Gonz'alez, 2005; Shaffer, 2004). To estimate $M C_{i}$, the first derivative of translog cost function ${ }^{3}$ with respect to $Q T Y_{i}$ is computed. The inability to econometrically estimate marginal cost account for the recent application in literature of Lerner index has been known among economists since the mid-30s. Marginal cost is extracted from the cost function through a translog approach.

The translog cost function, used generally in finance (Berger et al., 2009; Kouki and Al-Nasser, 2014) is an expression of a specific production model which for this study is assumed to be specified as the translog production function ${ }^{4}$. The name translog stands for transcendental logarithmic, in other words, translog cost function is a second-order Taylor series expansion of banks cost in natural logarithm. The general form of Taylor series expansion for a function involving more than one variable is given by the expression below;

$$
\begin{aligned}
& T\left(x_{1}, \ldots, x_{d}\right)=\sum_{n_{1}=0}^{\infty} \ldots \sum_{n_{d}=0}^{\infty} \frac{\left(x_{1}-a_{1}\right)^{n_{1}} \ldots\left(x_{d}-a_{d}\right)^{n_{d}}}{n_{1} ! \ldots n_{d} !}\left(\frac{\delta^{n_{1}+\ldots+n_{d f}}}{\delta x_{1}^{n_{1}} \ldots \delta x_{d}^{n_{d}}}\right)\left(a_{1}, \ldots, a_{d}\right) \\
& =f\left(a_{1}, \ldots, a_{d}\right)+\sum_{j=1}^{d} \frac{\delta f\left(a_{1}, \ldots, a_{d}\right)}{\delta x_{j}}\left(x_{j}-a_{j}\right)+\frac{1}{2 !} \sum_{j=1}^{d} \sum_{k=1}^{d} \frac{\delta^{2} f\left(a_{1}, \ldots, a_{d}\right)}{\delta x_{j} \delta x_{k}} \\
& \left(x_{j}-a_{j}\right)\left(x_{k}-a_{k}\right)+\ldots
\end{aligned}
$$

Based on the definition of translog cost function, the generalised translog production function which takes into account of $n$ inputs (Coelli and Rao, 1998) is given below;

\footnotetext{
${ }^{3}$ Another way to estimate cost function is the average variable cost expressed as the ratio of total variable cost to total asset or total income. Although this seems a simpler and straight forward approach, it has been argued to be inaccurate.

${ }^{4}$ Some other common production functional forms include; linear, Cobb-Douglas, quadratic, normalised quadratic, constant elasticity of substitution and generalised Leontief functions.
} 


$$
\ln (Y)=\beta_{0}+\sum_{n=1}^{N} \beta_{n} \ln \left(X_{n}\right)+\frac{1}{2} \sum_{n=1}^{N} \sum_{m=1}^{N} \beta_{n m} \ln \left(X_{n}\right) \ln \left(X_{m}\right)
$$

Where $Y$ is output, $\ln$ is the natural logarithm, $X_{n}$ are the inputs, $\beta_{0}, \beta_{n}$, and $\beta_{n m}$ are the model parameters. More precisely, $\beta_{n}$, and $\beta_{n m}$ are the first and the second partial derivatives.

Relying on the intermediation approach for measuring bank output (Ajisafe and Akinlo, 2013; Sealey and Lindley, 1977) the total cost of banks consists of one output, $Q T Y$, and three inputs, $W_{1}, W_{2}$, and $W_{3}$, representing price of labour (ratio of personnel expense to total assets), price of physical capital (non-interest expense to fixed assets) and price of fund (interest expense to total deposits) respectively. Hence, the total cost function of banks is given by;

$$
C=F\left(Q T Y, W_{1}, W_{2}, W_{3}\right)
$$

We substitute Equation (1.4) in the generalised translog production function in Equation (1.3). This produced the translog cost function as shown in Equation (1.5) which was obtained by approximating the logarithm of the total cost function by a function of the logarithm of the output and inputs. For the purpose of this work and for simplicity, we drop subscript it and denote $W_{1}, W_{2}$, and $W_{3}$ as $K, L$, and $M$ respectively in subsequent equations unless otherwise stated.

$$
\begin{aligned}
& \ln (C)=\beta_{0}+\beta_{q} \ln (Q T Y)+\beta_{K} \ln (K)+\beta_{l} \ln (L)+\beta_{m} \ln (M)+\frac{1}{2}\left[\beta_{q q} \ln (Q T Y) \ln (Q T Y)\right. \\
& +\beta_{q k} \ln (Q T Y) \ln (K)+\beta_{k q} \ln (K) \ln (Q T Y)+\beta_{q l} \ln (Q T Y) \ln (L)+\beta_{l q} \ln (L) \ln (Q T Y) \\
& +\beta_{q m} \ln (Q T Y) \ln (M)+\beta_{m q} \ln (M) \ln (Q T Y)+\beta_{k k} \ln (K) \ln (K)+\beta_{k l} \ln (K) \ln (L) \\
& +\beta_{l k} \ln (L) \ln (K)+\beta_{k m} \ln (k) \ln (n)+\beta_{m k} \ln (M) \ln (K)+\beta_{l l} \operatorname{in}(L) \ln (L) \\
& \left.+\beta_{l m} \ln (L) \ln (M)+\beta_{m l} \ln (M) \ln (L)+\beta_{m m} \ln M \ln (M)\right]+\mu
\end{aligned}
$$

Recall from basic partial derivatives that $f_{x y}=f_{y x}$ for any function with two variables. Hence, the second order cross derivatives of the form, $\beta_{n m}=\beta_{m n}$. Based on this, Equation (1.5) is simplified thus:

$$
\begin{aligned}
& \ln (C)=\beta_{0}+\beta_{q} \ln (Q T Y)+\beta_{K} \ln (K)+\beta_{l} \ln (L)+\beta_{m} \ln (M)+\frac{1}{2} \beta_{q q} \ln (Q T Y)^{2} \\
& +\frac{1}{2}\left[2 \beta_{q k} \ln (Q T Y) \ln (K)+2 \beta_{q l} \ln (Q T Y) \ln (L)+2 \beta_{q m} \ln (Q T Y) \ln (M)\right] \\
& +\frac{1}{2}\left[\beta_{k k} \ln (K) \ln (K)+\beta_{k l} \ln (K) \ln (L)+\beta_{l k} \ln (L) \ln (K)+\beta_{k m} \ln (k) \ln (n)\right. \\
& +\beta_{m k} \ln (M) \ln (K)+\beta_{l l} \ln (L) \ln (L)+\beta_{l m} \ln (L) \ln (M)+\beta_{m l} \ln (M) \ln (L) \\
& \left.+\beta_{m m} \ln M \ln (M)\right]+\mu
\end{aligned}
$$


Rearranging Equation (1.6) and simplifying it further by collecting like times, it becomes,

$$
\begin{aligned}
& \ln (C)=\beta_{0}+\beta_{q} \ln (Q T Y)+\frac{1}{2} \beta_{q q} \ln (Q T Y)^{2}+\beta_{K} \ln (K)+\beta_{l} \ln (L)+\beta_{m} \ln (M) \\
& +\beta_{q k} \ln (Q T Y) \ln (K)+\beta_{q l} \ln (Q T Y) \ln (L)+\beta_{q m} \ln (Q T Y) \ln (M)+\frac{1}{2}\left[\beta_{k k} \ln (K) \ln (K)\right. \\
& +\beta_{k l} \ln (K) \ln (L)+\beta_{l k} \ln (L) \ln (K)+\beta_{k m} \ln (k) \ln (n)+\beta_{m k} \ln (M) \ln (K)+\beta_{l l} \ln (L) \ln (L) \\
& \left.+\beta_{l m} \ln (L) \ln (M)+\beta_{m l} \ln (M) \ln (L)+\beta_{m m} \ln M \ln (M)\right]+\mu
\end{aligned}
$$

We chose for simplicity to represent the parameters; $\beta_{q}=\beta_{1}, \beta_{q q}=\beta_{2}$, $\beta_{k, l, m}=\theta_{1,2,3}, \quad \beta_{q k, q l, q m}=\oint_{1,2,3}, \quad \beta_{k k, k l, k m}=\emptyset_{11,12,13}, \quad \beta_{l k, l l, l m}=\emptyset_{21,22,23}$, $\beta_{m k, m l, m m}=\emptyset_{31,32,33}$, and to transform the variables back to their original form such that Equation (1.7) becomes;

$$
\begin{aligned}
& \ln (C)=\beta_{0}+\beta_{1} \ln (Q T Y)+\frac{1}{2} \beta_{2} \ln (Q T Y)^{2}+\theta_{1} \ln \left(W_{1}\right)+\theta_{2} \ln \left(W_{2}\right)+\theta_{3} \ln \left(W_{3}\right) \\
& +\oint_{1} \ln (Q T Y) \ln \left(W_{1}\right)+\oint_{2} \ln (Q T Y) \ln \left(W_{2}\right)+\int_{3} \ln (Q T Y) \ln \left(W_{3}\right)+\frac{1}{2}\left[\varnothing_{11} \ln \left(W_{1}\right) \ln \left(W_{1}\right)\right. \\
& +\varnothing_{12} \ln \left(W_{1}\right) \ln \left(W_{2}\right)+\varnothing_{13} \ln \left(W_{1}\right) \ln \left(W_{3}\right)+\varnothing_{21} \ln \left(W_{2}\right) \ln \left(W_{1}\right)+\varnothing_{22} \ln \left(W_{2}\right) \ln \left(W_{2}\right) \\
& \left.+\varnothing_{23} i n\left(W_{2}\right) \ln \left(W_{3}\right)+\varnothing_{31} \ln \left(W_{3}\right) \ln \left(W_{1}\right)+\varnothing_{32} \ln \left(W_{3}\right) \ln \left(W_{2}\right)+\varnothing_{33} \ln W_{3} \ln \left(W_{3}\right)\right]+\mu
\end{aligned}
$$

The reduced translog cost function (Equation (1.9)) in panel form by bringing back the subscript $i$ that we dropped for simplicity and in introducing time, $t$, to the model is shown below.

$$
\begin{aligned}
& \ln (C)=\beta_{0}+\beta_{1} \ln \left(Q T Y_{i t}\right)+\frac{1}{2} \beta_{2} \ln \left(Q T Y_{i t}^{2}\right)+\sum_{k=1}^{3} \theta_{k} \ln \left(W_{k i t}\right)+\sum_{k=1}^{3} f_{k} \ln \left(Q T Y_{i t}\right) \ln \left(W_{k i t}\right) \\
& +\frac{1}{2} \sum_{k=1}^{3} \sum_{j=1}^{3} \varnothing_{k j} \ln \left(W_{k i t}\right) \ln \left(W_{j i t}\right)+\mu_{i t}
\end{aligned}
$$

Where $Q T Y_{i t}$ is bank output measured as the natural log of total assets of bank $i$ in time $t$ (de Guevara and Maudos, 2011), $W_{k i t}$ is the vector of the three input prices and $\mu_{i t}$ is the error term.

Taking the first derivative of the translog cost function with respect to output give the marginal cost as follows:

$$
M C_{i t}=\frac{\delta C_{i t}}{\delta Q T Y_{i t}}=\frac{1}{Q T Y_{i t}}\left(\beta_{1}+\beta_{2} \ln \left(Q T Y_{i t}\right)+\sum_{k=1}^{3} \int_{k} \ln \left(W_{k i t}\right)\right)
$$


Substituting Equation (1.10) for marginal cost in Equation (1.1), the degree of competition will be computed using;

$$
L I_{i t}=\frac{P_{i t}-\frac{1}{Q T Y_{i t}}\left(\beta_{1}+\beta_{2} \ln \left(Q T Y_{i t}\right)+\sum_{k=1}^{3} \mathfrak{d}_{k} \ln \left(W_{k i t}\right)\right)}{P_{i t}}
$$

According to Leon (2015a), the Lerner index for market $\mathrm{j}$ is obtained as follows;

$$
L_{j}=\sum_{i \in j} \phi_{i j} L_{i j}
$$

Where $L_{i j}$ is the Lerner index of bank $i$ in market or country $j$ and $\varphi_{i j}$ the weighting of bank $i$ (often the market share of bank $i$ in market $j$ ). An unweighted Lerner index implies that $\phi_{i}=\frac{1}{N}$, where $N$ is the number of banks in market $j$. Market share has been proxied in literature using the total assets of banks relative to industry, market or country's total asset (Ahokpossi, 2013).

The model for the estimation of the determinants of the competitive condition of the SSA commercial banks is based on Arellano and Bond (1991) and Arellano and Bover (1995) generalised method of moments (GMM). This permits the capturing of the commercial banks specific variables that drive competition while controlling for a range of macroeconomic variables. The estimable version of the model is expressed below;

$$
l i_{k i t}=\delta_{k i t}+\lambda l i_{k i t-1}+\psi_{k i t} \Sigma \chi_{k i t}+\varrho_{k i t} \Sigma \aleph_{k i t}+v_{k i t}
$$

Where the subscripts $k_{i t}$ signifies bank, country and year respectively. $L i$ measures bank level competition with its one period lag value, $\delta$ is the intercept while $\lambda, \psi, \varrho$ are coefficients. $\Sigma \chi$ represents the range of banks' specific variables that drives competition, these are; equity capital ratio (ECR), liquidity ratio (LAR), assets quality (QLTY), return on assets (ROA), return on equity (ROE) and net interest margin (NIM). The macroeconomic variables considered are gross domestic product annual growth (GDPG) and annual inflation rate (INF) denoted by $\Sigma \aleph$ with $v$ as the error term.

\subsection{Data}

To compute the degree of competitiveness of SSA commercial banks, this study uses the individual bank level annual data sets of 440 banks financial profiles from 37 African countries for the periods 2006 - 2015. The choice of period is informed by data availability on BankScope database compiled by Fitch/IBCA Bureau van Dijk. We excluded countries ${ }^{5}$ with issues on data integrity and those we considered outliers.

\footnotetext{
${ }^{5}$ For instance, South Africa was considered an outlier because of the sophistication of the banking sector and countries like Congo and Sudan were excluded for paucity and integrity of data, resulting from the fact that their economies have been ravaged by wars.
} 
Data on personnel expenses include wages and salaries, social security contributions, contributions to pension funds and other related labour expenses (Delis et al., 2008). For interest expenses, data collected include interests on current accounts, savings accounts, time deposits, repurchase agreements and alternative funding sources such as retail bonds (Tan, 2013; Wang et al., 2014). Non-interest expenses comprise data on administration expenses which include rents, service charges, security, communication and information systems, other office and insurance expenses, professional charges, publicity and advertising, plus depreciation. Data on total revenue include both interest revenue, other operating income and non-interest income. The increase in non-interest income overtime in banking has prompted the use of total revenue in banking research in the recent time (Ajisafe and Akinlo, 2013; Prasad and Ghosh, 2005; Berger et al., 2009).

For the purpose of the determinants of banking competition in the SSA region, we follow (Hussain and Mustapha, 2010) to select bank specific variables of capital, liquidity, quality of assets and profitability measures of banks as potential determinants of bank competition. They argued that changes in these variables have the effects of changing the overall banking conditions, thus hypothesise a logical link to competition. In addition, we included two macroeconomics variables of annual GDP growth and inflation due to the macroeconomic nature of the banking system.

\section{Empirical Results}

In Tables 1 and 2 below are the results of the competition indices for the SSA commercial banks for the period 2006-2015. We had in Subsection 3.1 modelled the translog cost fiction for the variant of Lerner index used to capture the core activities of commercial banks in the SSA region based on Sealey and Lindley (1977) as their activities to the present are still predominantly intermediation in nature. Hence, Table 2 below contains the summary statistics of the bank level competition reflective of this model. This summary revealed some interesting features of the competitive nature of the banking environment in the SSA region. We found that competition index/degree of market power for individual banks ranges between 0 in 2013 and 0.9978 in 2012 as depicted by the minimum and maximum values. The implication of this is that while some countries have absolute very low market power, others have very high degree of market power with the ability to control a large chunk of the banking environment. However, we found that despite the high degree of market power, the means of the indices are close to the minimum value. We can deduce two possible implications from this. Firstly, is implied that banks with a high the degree of market power are few and in some cases, they are isolated case. This is consistent with literature; using concentration ratio, we found some degree of concentration in the banking sectors of the SSA region. Secondly, the means being close to the minimum suggest some form of competition within the banking sector as the minimum values are close to zero which meant a monopolistic competitive banking market. The standard deviation which measures the deviation from the mean affirms our suspicion providing credence to the conclusion of a competitive banking system. 
Table 1: Bank Level's Competition Index Summary Statistics

\begin{tabular}{ccccc}
\hline Year & Mean & SD & Min & Max \\
\hline 2006 & 0.2557 & 0.1656 & 0.0006 & 0.8370 \\
2007 & 0.2694 & 0.1557 & 0.0129 & 0.7842 \\
2008 & 0.2884 & 0.1773 & 0.0109 & 0.9674 \\
2009 & 0.2939 & 0.1884 & 0.0102 & 0.9213 \\
2010 & 0.2959 & 0.1829 & 0.0004 & 0.9790 \\
2011 & 0.2822 & 0.1728 & 0.0030 & 0.9767 \\
2012 & 0.3237 & 0.1945 & 0.0050 & 0.9978 \\
2013 & 0.3350 & 0.3143 & 0.0000 & 0.9881 \\
2014 & 0.3318 & 0.1855 & 0.0003 & 0.9963 \\
2015 & 0.3244 & 0.1964 & 0.0006 & 0.9957 \\
\hline
\end{tabular}

Source: Authors' Estimation, 2017

\subsection{Competition analysis}

Specifically, Table 2 shows the results of competition depicting a varying degree of market power in the commercial banking sectors during the periods considered. The total column shows the average index for the countries in the sample and the row total shows the yearly distribution of the index of market power from 2006 to 2016 for the SSA region. Overall, the SSA region's commercial bank competition index stood at 0.2460 during the period of this study. While most countries have their indices below the mean, we found only about six countries above the mean. Furthermore, the results show that out of the six countries with an index above the mean, Botswana, Malawi and Namibia belong to the Southern Africa region with $0.3454,0.3804$ and 0.3784 respectively. Ghana and Nigeria in West Africa also have 0.4352 and 0.3448 with Uganda in East Africa at 0.4221 . This suggests that these regions may have the most concentration of market power compared to other regions such as the SSA.

The graphs in Figure 1 and Figure 2 above provide a cursory look at the foregoing results, depicting the analysis of the trend of competition in the regions within the periods under review. Specifically, the graph in Figure 1 represents the country analysis of competition providing a pictorial view of the descriptions attempted above. It suffices to say that the graph shows clearly the distinction of market power amidst the countries of the region, with Ethiopia having the least at 0.0377 and Ghana with the highest at 0.4352 . Figure 2's graph depicts the evolution of commercial bank year-onyear competition/market power in the SSA region from 2006 to 2015. The indices peaked in 2008 at 0.2659 and least in 2015 at 0.2300 . We noted from the graph that there is a downward trend in market power over the period as indicated by the trend line. This downward movement was maintained except in 2013 when it rose and dropped thereafter. 
Table 2: SSA Region Competition Index

\begin{tabular}{|c|c|c|c|c|c|c|c|c|c|c|c|}
\hline Country & 2006 & 2007 & 2008 & 2009 & 2010 & 2011 & 2012 & 2013 & 2014 & 2015 & Total \\
\hline Angola & 0.065421 & 0.097832 & 0.120411 & 0.124526 & 0.258332 & 0.207652 & 0.31061 & 0.230903 & 0.204018 & 0.213769 & 0.183347 \\
\hline Benin & 0.18813 & 0.268522 & 0.074342 & 0.079369 & 0.109372 & 0.179535 & & & 0.191783 & 0.028362 & 0.139927 \\
\hline Botswana & 0.41853 & 0.495537 & 0.415291 & 0.398058 & 0.352876 & 0.261277 & 0.290714 & 0.280079 & 0.279677 & 0.261429 & 0.345347 \\
\hline Burkina Faso & 0.071393 & 0.135803 & 0.046363 & 0.068002 & 0.103534 & 0.154452 & 0.086129 & 0.095664 & 0.035652 & 0.018208 & 0.08152 \\
\hline Cameroon & 0.226445 & 0.100812 & 0.12154 & 0.35474 & 0.38554 & 0.391537 & 0.495393 & 0.515827 & 0.372902 & 0.247272 & 0.321201 \\
\hline CapeVerde & & & 0.080306 & 0.08957 & 0.166683 & 0.126485 & 0.097364 & 0.065904 & & 0.016599 & 0.091845 \\
\hline CAR & 0.466527 & 0.28377 & 0.567765 & 0.092447 & 0.127969 & 0.132734 & 0.077789 & 0.046362 & 0.122516 & & 0.213098 \\
\hline Chad & 0.837031 & 0.387705 & 0.275987 & 0.261423 & 0.207221 & 0.296301 & 0.092021 & 0.181206 & 0.147656 & 0.146466 & 0.283302 \\
\hline Djibouti & 0.101319 & 0.092217 & 0.187151 & 0.074287 & & 0.274413 & 0.518477 & 0.467877 & 0.380818 & 0.358804 & 0.272818 \\
\hline E. Guinea & & & & & & & & & 0.274265 & 0.188215 & 0.23124 \\
\hline Ethiopia & & & 0.036623 & & & & 0.01417 & 0.021523 & 0.054223 & 0.061985 & 0.037705 \\
\hline Gabon & 0.304602 & 0.339941 & 0.300123 & 0.257721 & 0.235867 & 0.167995 & 0.148784 & 0.282051 & 0.099412 & 0.119971 & 0.225647 \\
\hline Ghana & 0.445172 & 0.351556 & 0.348728 & 0.462851 & 0.457683 & 0.4031 & 0.429117 & 0.455854 & 0.48128 & 0.516627 & 0.435197 \\
\hline Guinea & 0.141299 & 0.312424 & 0.370526 & 0.074505 & 0.109427 & 0.071267 & & 0.145692 & & 0.175163 & 0.175038 \\
\hline Ivory Coast & 0.134617 & 0.161376 & 0.143645 & 0.064083 & 0.102507 & 0.119813 & 0.097698 & 0.115092 & 0.11904 & 0.126009 & 0.118388 \\
\hline Kenya & 0.245114 & 0.232857 & 0.277526 & 0.287116 & 0.291172 & 0.302607 & 0.409676 & 0.40179 & 0.385031 & 0.39278 & 0.322567 \\
\hline Lesotho & & 0.2254 & 0.358871 & 0.233187 & 0.171759 & 0.134115 & 0.215399 & 0.285591 & 0.213069 & 0.133109 & 0.218944 \\
\hline Liberia & & & & & & & 0.023647 & & 0.20779 & & 0.115718 \\
\hline Malawi & 0.456018 & 0.353385 & 0.270827 & 0.30436 & 0.311011 & 0.322545 & 0.390127 & 0.436769 & 0.503659 & 0.455597 & 0.38043 \\
\hline Mali & 0.017308 & 0.053635 & 0.075161 & 0.110276 & 0.067184 & 0.092172 & 0.117589 & 0.116763 & 0.075745 & 0.018696 & 0.074453 \\
\hline Maunitania & 0.236234 & 0.093693 & 0.392847 & 0.255537 & 0.117236 & 0.544336 & 0.109889 & & 0.190124 & 0.275192 & 0.246121 \\
\hline Maunitius & 0.222107 & 0.247908 & 0.292037 & 0.261771 & 0.313006 & 0.250943 & 0.235541 & 0.176467 & 0.059297 & 0.590743 & 0.264982 \\
\hline Mozambique & 0.228342 & 0.351254 & 0.383867 & 0.308581 & 0.297472 & 0.381043 & 0.385831 & 0.285624 & 0.339606 & 0.306047 & 0.326767 \\
\hline Namibia & 0.444722 & 0.428396 & 0.45753 & 0.460304 & 0.415033 & 0.343708 & 0.281095 & 0.304976 & 0.292295 & 0.355685 & 0.378374 \\
\hline Niger & 0.053738 & & 0.213415 & 0.186278 & 0.312917 & 0.080205 & 0.070264 & 0.119265 & 0.075966 & 0.105901 & 0.135328 \\
\hline
\end{tabular}




\begin{tabular}{|c|c|c|c|c|c|c|c|c|c|c|c|}
\hline Country & 2006 & 2007 & 2008 & 2009 & 2010 & 2011 & 2012 & 2013 & 2014 & 2015 & Total \\
\hline Nigeria & 0.224949 & 0.308661 & 0.336525 & 0.450728 & 0.336709 & 0.279205 & 0.379483 & 0.392744 & 0.376448 & 0.362907 & 0.344836 \\
\hline Rwanda & & & 0.224498 & 0.264563 & 0.303845 & 0.361105 & 0.300362 & 0.269553 & 0.327953 & 0.297518 & 0.293675 \\
\hline Senegal & 0.248176 & 0.282613 & 0.299681 & 0.292004 & 0.21978 & 0.275542 & 0.147133 & 0.251955 & 0.194679 & 0.123176 & 0.233474 \\
\hline Seychelles & & & & & 0.021818 & & & 0.27152 & 0.166672 & 0.083041 & 0.135763 \\
\hline Sierra Leone & 0.230387 & 0.238683 & 0.239474 & 0.278006 & 0.238491 & 0.270726 & 0.262031 & 0.275976 & 0.331167 & 0.290639 & 0.265558 \\
\hline Swaziland & 0.187937 & 0.283316 & 0.398314 & 0.247199 & 0.151684 & 0.087821 & 0.083403 & 0.051569 & 0.11542 & 0.114098 & 0.172076 \\
\hline Tanzania & 0.177395 & 0.25941 & 0.252369 & 0.281637 & 0.225099 & 0.19494 & 0.303348 & 0.288705 & 0.294501 & 0.289103 & 0.256651 \\
\hline The Gambia & 0.276819 & 0.346128 & 0.418295 & 0.459172 & 0.348642 & 0.258864 & 0.301389 & 0.189866 & 0.199847 & 0.271667 & 0.307069 \\
\hline Togo & 0.159375 & 0.170577 & 0.102373 & 0.059697 & 0.065713 & 0.018235 & 0.157644 & 0.188696 & 0.136832 & 0.09098 & 0.115012 \\
\hline Uganda & 0.367278 & 0.359364 & 0.3989 & 0.404256 & 0.442976 & 0.395169 & 0.425404 & 0.48976 & 0.492994 & 0.445247 & 0.422135 \\
\hline Zambia & 0.297172 & 0.188736 & 0.294294 & 0.292279 & 0.346161 & 0.320364 & 0.185807 & 0.534413 & 0.277874 & 0.337614 & 0.307471 \\
\hline Total & 0.257709 & 0.256949 & 0.265927 & 0.244954 & 0.23796 & 0.240631 & 0.232604 & 0.257376 & 0.235889 & 0.229959 & 0.245996 \\
\hline
\end{tabular}

Sources: Authors' Estimation, 2016; based on Leon (2015a)'s market Lerner index

Fig. 1: SSA Competition Index by Country

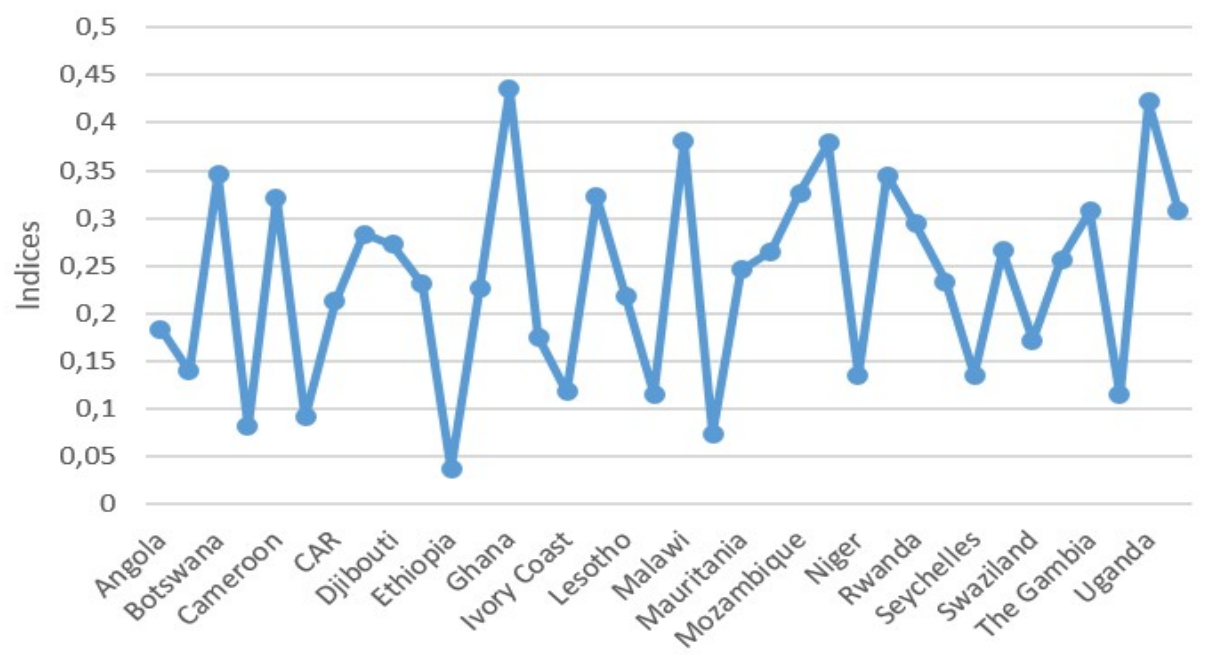

Countries 
Fig. 2: SSA Competition Index by Year

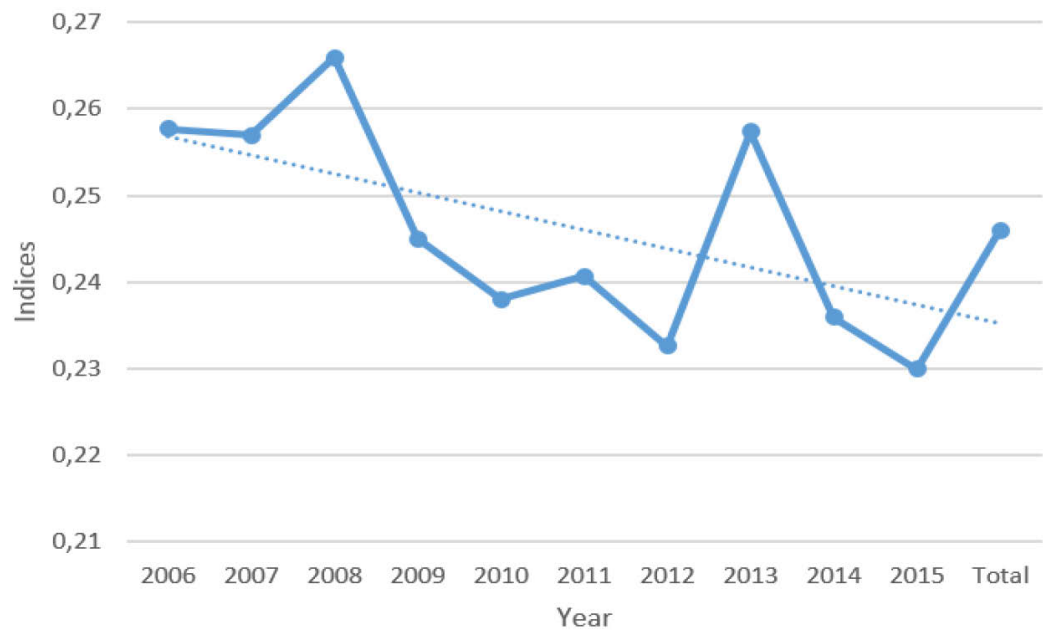

\subsection{Econometric Analysis}

The analysis of the determinant of competition in the commercial banking sectors of the SSA region is presented in Table 4 below with the correlation between the endogenous and the exogenous variables reported in Table 3 . We found a generally weak, but significant correlation between competition and the determinant variables for most part of the study period. ECR shows negative correlation all through the period while LR exhibits the same association except in 2006 wherein it is positive but rather too weak and insignificant. Although ALQTY shows a positive association, they are not statistically significant. The measures of profitability, ROA, ROE and NIM show positive correlation in most cases, but with mixed significance. This is the same for the macroeconomic variables, GDPG and INF. How much this influences competition will depend on whether the signs are consistent with the results of the econometric analysis in Table 4.

Table 3: Correlation Analysis

\begin{tabular}{lcccccccccc}
\hline & $\mathbf{2 0 0 6}$ & $\mathbf{2 0 0 7}$ & $\mathbf{2 0 0 8}$ & $\mathbf{2 0 0 9}$ & $\mathbf{2 0 1 0}$ & $\mathbf{2 0 1 1}$ & $\mathbf{2 0 1 2}$ & $\mathbf{2 0 1 3}$ & $\mathbf{2 0 1 4}$ & $\mathbf{2 0 1 5}$ \\
\hline li \& ecr & -0.143 & -0.282 & -0.046 & -0.145 & -0.337 & -0.333 & -0.306 & -0.013 & -0.098 & -0.023 \\
pvalue & 0.048 & 0.000 & 0.471 & 0.016 & 0.000 & 0.000 & 0.000 & 0.803 & 0.043 & 0.635 \\
\hline li \& Ir & 0.005 & 0.035 & -0.020 & -0.280 & -0.090 & -0.144 & -0.284 & -0.145 & -0.163 & -0.106 \\
pvalue & 0.949 & 0.611 & 0.760 & 0.000 & 0.127 & 0.010 & 0.000 & 0.004 & 0.001 & 0.028 \\
\hline li \& aqlty & 0.076 & 0.035 & 0.011 & 0.048 & 0.050 & 0.026 & -0.039 & 0.043 & 0.033 & 0.040 \\
pvalue & 0.335 & 0.636 & 0.873 & 0.453 & 0.425 & 0.662 & 0.495 & 0.429 & 0.532 & 0.441 \\
\hline li \& nim & 0.189 & 0.163 & 0.199 & 0.184 & 0.266 & 0.115 & 0.112 & 0.220 & 0.012 & 0.114 \\
pvalue & 0.010 & 0.018 & 0.002 & 0.003 & 0.000 & 0.042 & 0.036 & 0.000 & 0.803 & 0.019 \\
\hline
\end{tabular}




\begin{tabular}{lcccccccccc}
\hline & $\mathbf{2 0 0 6}$ & $\mathbf{2 0 0 7}$ & $\mathbf{2 0 0 8}$ & $\mathbf{2 0 0 9}$ & $\mathbf{2 0 1 0}$ & $\mathbf{2 0 1 1}$ & $\mathbf{2 0 1 2}$ & $\mathbf{2 0 1 3}$ & $\mathbf{2 0 1 4}$ & $\mathbf{2 0 1 5}$ \\
\hline li \& roa & 0.034 & 0.265 & 0.077 & 0.319 & 0.039 & -0.060 & 0.121 & 0.056 & 0.072 & 0.006 \\
pvalue & 0.643 & 0.000 & 0.224 & 0.000 & 0.504 & 0.288 & 0.022 & 0.270 & 0.139 & 0.897 \\
\hline li \& roe & -0.001 & 0.050 & 0.079 & 0.158 & 0.022 & 0.010 & 0.036 & 0.030 & 0.007 & -0.012 \\
pvalue & 0.994 & 0.472 & 0.218 & 0.009 & 0.703 & 0.861 & 0.500 & 0.552 & 0.882 & 0.806 \\
\hline li \& GDPG & -0.051 & 0.009 & 0.075 & 0.072 & 0.067 & 0.046 & 0.067 & 0.042 & 0.109 & 0.034 \\
pvalue & 0.485 & 0.892 & 0.239 & 0.231 & 0.253 & 0.409 & 0.205 & 0.412 & 0.023 & 0.494 \\
\hline li \& inf & 0.061 & -0.017 & 0.041 & 0.093 & 0.033 & 0.034 & 0.062 & 0.104 & 0.074 & 0.134 \\
pvalue & 0.404 & 0.805 & 0.520 & 0.126 & 0.569 & 0.542 & 0.240 & 0.040 & 0.129 & 0.008 \\
\hline
\end{tabular}

Source: Authors' Estimation, 2017

Our analysis followed the efficient estimation technique of (Arellano and Bond, 1991) to improve on (Hussain and Mustapha, 2010) and as well account for endogeneity. Hence, we employ the two-step system GMM approach with robust and orthogonal deviation option to analyse the determinant of commercial banks competition in the SSA region. Column 1 of Table 4 shows our main result while column 2 of the table serves as a robustness check on the result to investigate the sensitivity of the result to a further addition of bank specific variables that determines competition in the banking system in literature. The results, at a glance, show that previous year banking competition is a strong determinant of their current competition. This is evidenced by the positive and statistically significant coefficient of the lagged value of competition variable, LI. Contrary to the signs of the correlation result, but in line with our expectations and consistent with the study of Hussain and Mustapha (2010), we found capital, ECR, to be positive and strongly significant to explain competition. A $1 \%$ increase in capital is to induce about $4 \%$ increase in competitive pressure of the banking system. Both liquid assets, LAR, and asset quality, AQTLY exhibit strong significance, but negative relationship with competition. While this is consistent with the correlation results, we expect positive signs as banks are most likely going to find incentive to compete with more liquidity at their disposal, although issues of how much liquidity could be used up in the ordinary cause of their business is a subject of regulation. Similarly, the better the quality of asset the more competitive we expect the sector to be, however, the result might as well reflect the reality as the quality of asset in the study period is not particularly superb as shown in the descriptive statistics. All the performance measures employed, NIM, ROA and $\mathrm{ROE}$, and are significant and positively related to competition, with the exception of ROE that is negative. The results of ROA and NIM do not follow the study of Hussain and Mustapha (2010) who found them to be negatively related to competition in their studies. We indeed expect a profitable bank to find incentive to compete and this is the case with the SSA commercial banking sector. In closing, GDPG and INF are found to be positive and strongly significant to determine competition in the banking sector of the SSA region. This is in fact in line with a priori, growth period encourages more economic activities while in periods of rising price level banks would strive to keep their firm's value by competing the more. 
Table 4: GMM Regression Result

\begin{tabular}{|c|c|c|}
\hline VARIABLES & Model 1 lerneri & Model 2 lerneri \\
\hline L.lerneri & $\begin{array}{c}0.575^{* * *} \\
(0.000637)\end{array}$ & $\begin{array}{c}0.575^{* * *} \\
(0.000703)\end{array}$ \\
\hline size & & $\begin{array}{c}0.0978^{\star * *} \\
(0.0186)\end{array}$ \\
\hline ecr & $\begin{array}{c}4.218^{\star * *} \\
(0.222)\end{array}$ & $\begin{array}{c}4.493^{* * *} \\
(0245)\end{array}$ \\
\hline lar & $\begin{array}{l}-0.781^{* * *} \\
(0.0427)\end{array}$ & $\begin{array}{l}-0.647^{\star * *} \\
(0.0429)\end{array}$ \\
\hline aqlty & $\begin{array}{c}-1.180^{* * *} \\
(0.264)\end{array}$ & $\begin{array}{c}-0.980^{* * *} \\
(0.29)\end{array}$ \\
\hline nim & $\begin{array}{c}0.874^{* * *} \\
(0.18)\end{array}$ & $\begin{array}{c}1.157^{\star * *} \\
(0.195)\end{array}$ \\
\hline roa & $\begin{array}{c}0.0391^{* * *} \\
(0.0057)\end{array}$ & $\begin{array}{l}0.0279^{* * *} \\
(0.00609)\end{array}$ \\
\hline roe & $\begin{array}{c}-0.00402^{* * *} \\
(0.000786)\end{array}$ & $\begin{array}{l}-0.00324^{* * *} \\
(0.000817)\end{array}$ \\
\hline gdpg & $\begin{array}{c}0.500^{\star * *} \\
(0.146)\end{array}$ & $\begin{array}{c}0.524^{\star \star \star} \\
(0.145)\end{array}$ \\
\hline $\inf$ & $\begin{array}{c}0.00858^{* * \star} \\
(0.00123)\end{array}$ & $\begin{array}{c}0.00844^{\star * *} \\
(0.00126)\end{array}$ \\
\hline Constant & $\begin{array}{c}-0.387^{\star * *} \\
(0.0333)\end{array}$ & $\begin{array}{c}\left(-1.724^{* * *}\right. \\
(0.248)\end{array}$ \\
\hline Observations & 2.306 & 2.306 \\
\hline Number of id & 393 & 393 \\
\hline Number of instruments & 117 & 117 \\
\hline Wald $X^{2}(9)$ & $1.25 \mathrm{E}+06$ & $1.31 \mathrm{E}+06$ \\
\hline Prob $>x^{2}$ & 0.000 & 0.000 \\
\hline AR2 (p-value) & 0.285 & 0.297 \\
\hline Hansen J Stats ( $p$-value) & 0.373 & 0.388 \\
\hline
\end{tabular}

standard error in parentheses; ${ }^{* *} p<0.01,{ }^{* *} p<0.05,{ }^{*} p<0.1$.

Source: Authors' Estimation, 2017

For robustness, we introduced bank size as a determinant of competition in the banking system based on the structure-conduct-performance (SCP) hypothesis theory. We found that while size is positive to explain competition in the region; the inclusion does not change the signs and significance of the various determinants that were considered and discussed above.

The variation in the bank level market power index as shown by the margin between the maximum and the minimum values in the competition summary statistics in Table 1 of this study, is an indication of the pockets market concentration that is found to be prevalent in most Sub-Saharan African banking markets (Mlachila et al., 2013) and in our reviews. These call to mind whether the various regulations implemented to ensure a competitive banking system have fully actualised their aims. We have also found results that are consistent with studies in the extant literature as per the behaviour of bank level competition in a number of SSA countries in which similar studies have been carried out. Kouki and Al-Nasser (2014) found an average market power index of within $58 \%$ and $74 \%$ within the period $2005-2010$. Studies by 
Aboagye et al. (2008), Amidu (2013) and Ariss (2010) found a varying degree of market power in a number of countries that were studied.

In the case of market competition, it is not surprising, as already stated, to find a competitive market, which in this case is in the form of a monopolistic competitive market. This, no doubt, is informed by the contestable market theory of Baumol et al. (1982) who argued that even in the face of market power and/or market concentration, a market could be contestable, as the threat of entry will impact on the behaviour of the incumbents in the market. How much this competition has impacted on the extent of financial intermediation as the core banking function in the region has left much to be desired. As shown in statistics by the World Bank Development Indicators over our study period, interest rate spread is high, banks credit to the private sector is low, lending cost is high, while deposit rates could not be said to be moderate, and banking coverage is low on aggregate. These indicators are not consistent with a competitive market environment, which should mean the reverse. Unfortunately, banks in the region are being accused of competing for government funds rather than mobilising surplus for deficit financing of the real sector of the economy, which could engender an overall growth in the long term. It is also noteworthy to argue that other factors relating to state policies that favour certain banks over the others, and a range of other exogenous factors other than were discussed here account for why the current competitive nature of the banking system could not help to impact on these development indicators in the region and we recommend further studies to investigate these. This, notwithstanding policy implication, will be to seek macroeconomic policies that gel with relevant statutory pronouncements and will complement the current level of market competition, while continually working to encourage the antitrust authorities to keep market power as low as practicable.

Ultimately, we found all the bank specific variables considered to be significant in determining the level of competition in the region. Capital especially increased the level of competition considerably as well as the level of performance including macroeconomics variable of annual GDP growth and inflation. Both the quality of assets and liquid assets were found to be indirectly related to the level of competition when, in fact, we expected a direct relationship. The fact that these variables can significantly influence competition in the region suggests that they can be tinkered with to moderate as well as increase the level of competition especially for a region that seeks to increase the competition conditions of its banking sectors.

\section{Summary and Conclusion}

The Lerner index has been used to analyse the bank level and market competitive condition of the SSA commercial banks. We took account of the various criticisms of the Lerner index, notably that it ignores risk which is fundamental in bank cost and price measurement that has no single acceptable measure. As plausible as the arguments may be, empirical evidence has shown that studies that have adjusted for these issues have not achieved much remarkable difference from the results of the conventional Lerner index. Moreover, studies of Liu et al. (2013) revealed the Lerner index to be one of the two must valid ways of measuring competition hence validating our methodology. We also modelled the translog cost function to reflect that the core activities of commercial banking sectors in the SSA region still remain that of intermediation. 
The study found a mixed market power at bank level across the 37 SSA countries that have been considered. Meanwhile, at market level lower market power is seen depicting a relatively competitive banking sector. Hence the study concludes that the SSA banking sector is competitive notwithstanding that it is laced with varying degree of market power. This thus give credence to the theory of contestable market that although there may be high market power residing in the banks, the threat of potential entry will make the market contestable. Mlachila et al. (2013); Senbet and Otchere (2006) found that banks in Africa and implied SSA countries jostle for government rather than performing the main financial intermediation role of mobilising surplus unit saving to bridge the gap of deficit units. We recommend that while the antitrust agency still needs to concentrate more efforts at devolving the market powers that reside in the individual banks, it should continuously maintain and improve on the market competition. Furthermore, fiscal and monetary policies must be harnessed to take advantage of the subsisting competitiveness of the region banking sector to cash in on the much-needed economic growth. Attention should also be paid to capital and other bank specific variables that impact on bank competition in the region. We also recommend studies should take into consideration the influence of state on the operations of the banking system in the region to further shed light on the nature of the system for a holistic policy implication.

\section{References}

Abdelkader, I. B. and Mansouri, F. (2013). Competitive conditions of the Tunisian banking industry: An application of the Panzar-Rosse model. African Development Review, 25(4):526-536.

Aboagye, A. Q., Akoena, S., Antwi-Asare, T., and Gockel, A. (2008). Explaining interest rate spreads in Ghana*. African Development Review, 20(3):378-399.

Agoraki, M.-E. K., Delis, M. D., and Pasiouras, F. (2011). Regulations, competition and bank risk-taking in transition countries. Journal of Financial Stability, 7(1):3848.

Ahokpossi, C. (2013). Determinants of bank interest margins in Sub-Saharan Africa.

Ajisafe, R. A. and Akinlo, A. E. (2013). Testing for competition in the Nigerian commercial banking sector.

Allen, F., Otchere, I., and Senbet, L. W. (2011). African financial systems: A review. Review of Development Finance, 1(2):79-113.

Amidu, M. (2013). The effects of the structure of banking market and funding strategy on risk and return. International Review of Financial Analysis, 28:143-155.

Arellano, M. and Bond, S. (1991). Some tests of specification for panel data: Monte carlo evidence and an application to employment equations. The review of economic studies, 58(2):277-297.

Arellano, M. and Bover, O. (1995). Another look at the instrumental variable estimation of error- components models. Journal of Econometrics, 68(1):29-51.

Ariss, R. T. (2010). On the implications of market power in banking: Evidence from developing countries. Journal of Banking \& Finance, 34(4):765-775.

Baumol, W. J., Panzar, J. C., Willig, R. D., Bailey, E. E., Fischer, D., and Fischer, D. (1982). Contestable markets and the theory of industry structure. The Canadian Journal of Economics, 15(4), 774. doi:10.2307/134928

Beck, T., De Jonghe, O., and Schepens, G. (2013). Bank competition and stability: crosscountry heterogeneity. Journal of Financial Intermediation, 22(2):218-244. 
Berg, S. A. and Kim, M. (1994). Oligopolistic interdependence and the structure of production in banking: an empirical evaluation. Journal of Money, Credit and Banking, 26(2):309-322.

Berger, A. N., Klapper, L. F., and Turk-Ariss, R. (2009). Bank competition and financial stability. Journal of Financial Services Research, 35(2):99-118.

Bikker, J. A. and Haaf, K. (2002). Competition, concentration and their relationship: An empirical analysis of the banking industry. Journal of Banking \& Finance, 26(11):2191-2214.

Boone, J. (2008a). Competition: Theoretical parameterizations and empirical measures. Journal of Institutional and Theoretical Economics JITE, 164(4):587-611.

Boone, J. (2008b). A new way to measure competition. The Economic Journal, 118(531):1245-1261.

Bresnahan, T. F. (1982). The oligopoly solution concept is identified. Economics Letters, 10(1):87-92.

Carb'o, S., Humphrey, D., Maudos, J., and Molyneux, P. (2009). Cross-country comparisons of competition and pricing power in European banking. Journal of International Money and Finance, 28(1):115-134.

Casu, B. and Girardone, C. (2006). Bank competition, concentration and efficiency in the single European market. The Manchester School, 74(4):441-468.

Casu, B., Girardone, C., and Molyneux, P. (2015). Introduction to banking, volume 10. Pearson Education.

Chirwa, E. W. (2003). Determinants of commercial banks' profitability in Malawi: A cointegration approach. Applied Financial Economics, 13(8):565-571.

Claessens, S. and Laeven, L. (2004). What drives bank competition? Some international evidence. Journal of Money, Credit and Banking, pages 563-583.

Clarke, G. R., Cull, R., and Peria, M. S. M. (2006). Foreign bank participation and access to credit across firms in developing countries. Journal of Comparative Economics, 34(4):774-795.

Coelli, T. and Rao, D. (1998). G. Battese (1998). An introduction to efficiency and productivity analysis. doi:10.1007/b136381

de Guevara, J. F. and Maudos, J. (2011). Banking competition and economic growth: Crosscountry evidence. The European Journal of Finance, 17(8):739-764.

De Guevara, J. F., Maudos, J., and P'erez, F. (2007). Integration and competition in the European financial markets. Journal of International Money and Finance, 26(1):26-45.

Delis, M. D., Staikouras, K. C., and Varlagas, P. T. (2008). On the measurement of market power in the banking industry. Journal of Business Finance \& Accounting, 35(7-8):1023-1047.

Demsetz, H. (1973). Industry structure, market rivalry, and public policy. The Journal of Law \& Economics, 16(1):1-9.

Dietsch, M. (1993). Localisation et concurrence dans la banque. Revue 'economique, pages 779-790. Fern'andez, A. I. and Gonz'alez, F. (2005). How accounting and auditing systems can counteract risk-shifting of safety-nets in banking: Some international evidence. Journal of Financial Stability, 1(4):466-500.

Flamini, V., Schumacher, M. L., and McDonald, M. C. A. (2009). The determinants of commercial bank profitability in Sub-Saharan Africa. Number 9-15. International Monetary Fund.

Freixas, X., Rochet, J.-C., et al. (2008). Microeconomics of banking, volume 2. MIT press Cambridge, MA. 
Fu, X. M., Lin, Y. R., and Molyneux, P. (2014). Bank competition and financial stability in Asia Pacific. Journal of Banking \& Finance, 38:64-77.

Heffernan, S. (2005). Modern banking. John Wiley \& Sons.

Hussain, M. E. and Mustapha, N. (2010). Determinants of bank competition. SSRN Electronic Journal. doi:10.2139/ssrn.2004746

Iwata, G. (1974). Measurement of conjectural variations in oligopoly. Econometrica: Journal of the Econometric Society, pages 947-966.

Klein, M. A. (1971). A theory of the banking firm. Journal of Money, Credit and Banking, 3(2):205-218.

Kouki, I. and Al-Nasser, A. (2014). The implication of banking competition: evidence from African countries. Research in International Business and Finance.

Lau, L. J. (1982). On identifying the degree of competitiveness from industry price and output data. Economics Letters, 10(1):93-99.

Leon, F. (2015a). Measuring competition in banking: A critical review of methods. Retrieved from https://halshs.archives-ouvertes.fr/halshs-01015794.

Leon, F. (2015b). What do we know about the role of bank competition in Africa? Retrieved from https://halshs.archives-ouvertes.fr/halshs-01164864

Lerner, A. P. (1934). Economic theory and socialist economy. The Review of Economic Studies, 2(1):51-61.

Lin, C., Ma, Y., and Song, F. M. (2010). Bank competition, credit information sharing and banking efficiency. In Sixth Asia Pacific Economic Association Conference, Hong Kong.

Liu, H., Molyneux, P., Wilson, J., et al. (2013). Competition in banking: Measurement and interpretation. Handbook of Research Methods and Applications in Empirical Finance, page 197.

Love, I. and Per'ıa, M. S. M. (2014). How bank competition affects firms' access to finance. The World Bank Economic Review, page Ihu003.

Maudos, J. and Sol'IS, L. (2011). Deregulation, liberalization and consolidation of the Mexican banking system: Effects on competition. Journal of International Money and Finance, 30(2):337-353.

Mlachila, M., Dykes, D., Zajc, S., Aithnard, P.-H., Beck, T., Ncube, M., and Nelvin, O. (2013). Banking in sub-Saharan Africa: Challenges and opportunities. Technical report, Regional Studies and Roundtables, European Investment Bank (EIB).

Mlambo, K. and Ncube, M. (2011). Competition and efficiency in the banking sector in South Africa. African Development Review, 23(1):4-15.

Molyneux, P., Lloyd-Williams, D. M., and Thornton, J. (1994). Competitive conditions in European banking. Journal of Banking \& Finance, 18(3):445-459.

Monti, M. (1972). Deposit, credit and interest rate determination under alternative bank objective function. North-Holland/American Elsevier.

Mudd, S. (2013). Bank structure, relationship lending and small firm access to finance: A cross-country investigation. Journal of Financial Services Research, 44(2):149-174.

Mueller, D. C. (1977). The persistence of profits above the norm. Economica, 44(176):369 380. Mueller, D. C. (1986). Profits in the long run. Cambridge University Press.

Ningaye, P., Mathilde, M. Y., and Luc, N. N. (2014). Competition and banking efficiency in the cemac zone. International Journal of Economics and Finance, 6(6):127.

Northcott, C. A. et al. (2004). Competition in banking: A review of the literature. Bank of Canada Working Paper.

Panel, A. P. (2014a). Grain, Fish, Money: Financing Africa's Green and Blue Revolutions. Africa Progress Panel. 
Panel, A. P. (2014b). Green fish money financing Africa's green and blue revolution. Africa progress report.

Panzar, J. C. and Rosse, J. N. (1977). Chamberlin versus Robinson: An empirical test for monopoly rents. Workshop on Applied Microeconomics, Industrial Organization, and Regulation, Department of Economics, Stanford Univ.

Panzar, J. C. and Rosse, J. N. (1987). Testing for "monopoly" equilibrium. The Journal of Industrial Economics, pages 443-456.

Pasiouras, F., Delis, M. D., and Papanikolaou, N. I. (2009). Determinants of bank efficiency: evidence from a semi-parametric methodology. Managerial Finance, 35(3):260275.

Posner, R. A. (1979). The Chicago school of antitrust analysis. University of Pennsylvania Law Review, 127(4):925-948.

Prasad, A. and Ghosh, S. (2005). Competition in Indian banking. Number 2005-2141. International Monetary Fund.

Pruteanu-Podpiera, A., Weill, L., and Schobert, F. (2008). Banking competition and efficiency: A micro- data analysis on the Czech banking industry. Comparative Economic Studies, 50(2):253-273.

Rice, T. and Strahan, P. E. (2010). Does credit competition affect small-firm finance? The Journal of Finance, 65(3):861-889.

Rojas, C. (2011). Market power and the Lerner index: a classroom experiment. Journal of Industrial Organization Education, 5(1):1-19.

Schaeck, K. and Cih'ak, M. (2014). Competition, efficiency, and stability in banking. Financial Management, 43(1):215-241.

Sealey, C. W. and Lindley, J. T. (1977). Inputs, outputs, and a theory of production and cost at depository financial institutions. The Journal of Finance, 32(4):1251-1266.

Senbet, L. W. and Otchere, I. (2006). Financial sector reforms in Africa: perspectives on issues and policies. In Annual World Bank Conference on Development Economics 2006: Growth and Integration, pages 81-120.

Shaffer, S. (2004). Comment on" what drives bank competition? some international evidence" by Stijn Claessens and Luc Laeven. Journal of Money, Credit and Banking, 36(3):585-592.

Shepherd, W. G. (1983). Economies of scale and monopoly profits. In Industrial Organization, Antitrust and Public Policy, pages 165-204. Springer.

Smirlock, M., Gilligan, T., and Marshall, W. (1986). Tobin's q and the structure-performance relationship: reply. The American Economic Review, 76(5):1211-1213.

Tan, Y. (2013). Essays on the analysis of performance and competitive condition in the Chinese banking industry. $\mathrm{PhD}$ thesis, University of Portsmouth.

Wang, X., Zeng, X., and Zhang, Z. (2014). The influence of the market power of Chinese commercial banks on efficiency and stability. China Finance Review International, 4(4):307-325.

Weill, L. (2013). Bank competition in the EU: How has it evolved? Journal of International Financial Markets, Institutions and Money, 26:100-112. 